\title{
Danske arkitekter i Flensborg omkring 1850
}

\section{Af Hans Munk Hansen}

Flensborgs ophøjelse til regeringsby for hertugdømmet Slesvig efter treårskrigen og anlægget af den slesvigske jernbane bevirkede en opblomstring af byggeaktiviteten i byen. Ved udformningen af både offentlige og private bygninger, spillede danske arkitekter udgået fra kunstakademiet i København den væsentlige rolle. I kunsthistorien har arkitekturen fra midten af 1800-tallet hidtil ikke påkaldt sig den store interesse, og vurderingen af denne tids bygninger i Flensborg er oftest faldet negativt ud. I dag ser man dog med nye øjne på perioden.

Allerede nu beklager næsten alle tabet af Winstrups regeringsbygninger på Holmen, til fordel for en varehusmastodont, og Latinskolen $\mathrm{i}$ Rødegade, der måtte vige for en garage. Men det var ikke kun Flensborg, der blev ramt af efterkrigstidens manglende respekt for det foregående århundredes arkitektur. Heller ikke i København forstår man idag, at det for bare et årti siden kunne tillades at rive Herholdts smukke Nationalbank ned. Eller et mere nært eksempel: at det forenemme senklassisicistiske »Ahlmanns hus« i Gråsten forsvandt for få år siden.

I Danmark var midten af 1800 -tallet $i$ endnu højere grad end i det $\emptyset$ vrige Europa en brydningens og fornyelsens tid for arkitekturen. Her havde klassicismen med sine store personligheder C.F. Hansen og Thorvaldsen været enerådende meget længe, indtil der med G.F. Hetsch som leder af kunstakademiets arkitektskole i København fra 1835 til 1864 endelig blev åbnet op for nye strømninger.

Hetsch var en fremragende, international orienteret lærer. ${ }^{1}$ Han var født i Stuttgart og havde studeret i Paris. Hans elever gjorde sig gældende overalt i Europa som f.eks. Teophilos Hansen i Wien og Christian Hansen i Athen.

Arkitekturens store problem var at give udtryk for det nye samfund, som udviklede sig under industrialismens gennembrud. Flere tendenser gjorde sig gældende ved siden af hinanden. Klassicismen levede videre som senklassicisme under stærk påvirkning af den berømte arkitekt Schinkel i Berlin. 


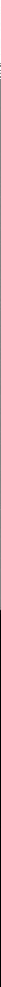

Flensborgs sydlige bydel $i 1863$ med de $i$ artiklen omtalte bygninger:

A. Latinskolen $i$ Rodegade.

B. Hargens hus (Lutherhaus)

C. C. Lauths hus på Reberbanen.

D. Andreas Christiansens hus. (Stadt-Sparkasse, Holmen)

E. Regeringsbygningerne. ("Hertie", Holmen)

F. Storegade 48.

G. Banegården.

Samtidig spillede romantikken en afgørende rolle $\mathrm{i}$ bygningskunsten. Grundtvig og kunsthistorikeren Høyen efterlyste huse, der var $\mathrm{i}$ overensstemmelse med nordens kultur. Gotikken blev anset for særlig nordisk og fik en genopblomstring. Efterhånden blev dog også andre perioders arkitektur taget op. I den frie historicisme tjente alle stilperioders formelementer som arsenal for arkitekterne.

Som en tredie retning og spirende start til vort århundredes arkitektur begyndte også sagligheden at gøre sig gældende. Nye bygningstyper til industri og offentlighed samt anvendelsen af nye materialer som jern, glas og beton inspirerede til en arkitektur, hvor afklarede konstruktioner og stoflighed spillede en større rolle end arkitektoniske ornamenter. De danske arkitekter, som virkede i Flensborg efter århundredets midte, levede ivrigt med $\mathrm{i}$ tidens strømninger. 
L.A. Winstrup (1819-89) var født i København og havde fået den traditionelle arkitektudddannelse på kunstakademiet, der også omfattede studierejser til udlandet. ${ }^{2}$ Han blev senere medarbejder hos professor Hetsch og assisterede også denne ved undervisning på akademiet. I 1848 vandt Winstrup den store guldmedalje på et projekt til et teater tegnet helt i Schinkels ånd. ${ }^{3}$ Guldmedaljen indbragte Winstrup akademiets flereårige rejsestipendie til Italien. Fra Rom ansøgte han i 1851 om embedet som stadsbygmester i Flensborg. ${ }^{4}$ Winstrup fik stillingen og tiltrådte samme år. Foruden byens byggesager løste Winstrup også opgaver for staten, kirkerne, kongen (på Glyksborg) og for private bygherrer. I 1860 blev Winstrup udnævnt til kgl. bygningsinspektør. Han flyttede til Kolding, men gennemførte herfra stadigvæk arbejder i Flensborg. I 1862 fik Winstrup titel som professor.

Winstrups væsentligste opgaver for det offentlige i Flensborg var regeringsbygningen på Holmen og Latinskolen ved Rødeport. Win-

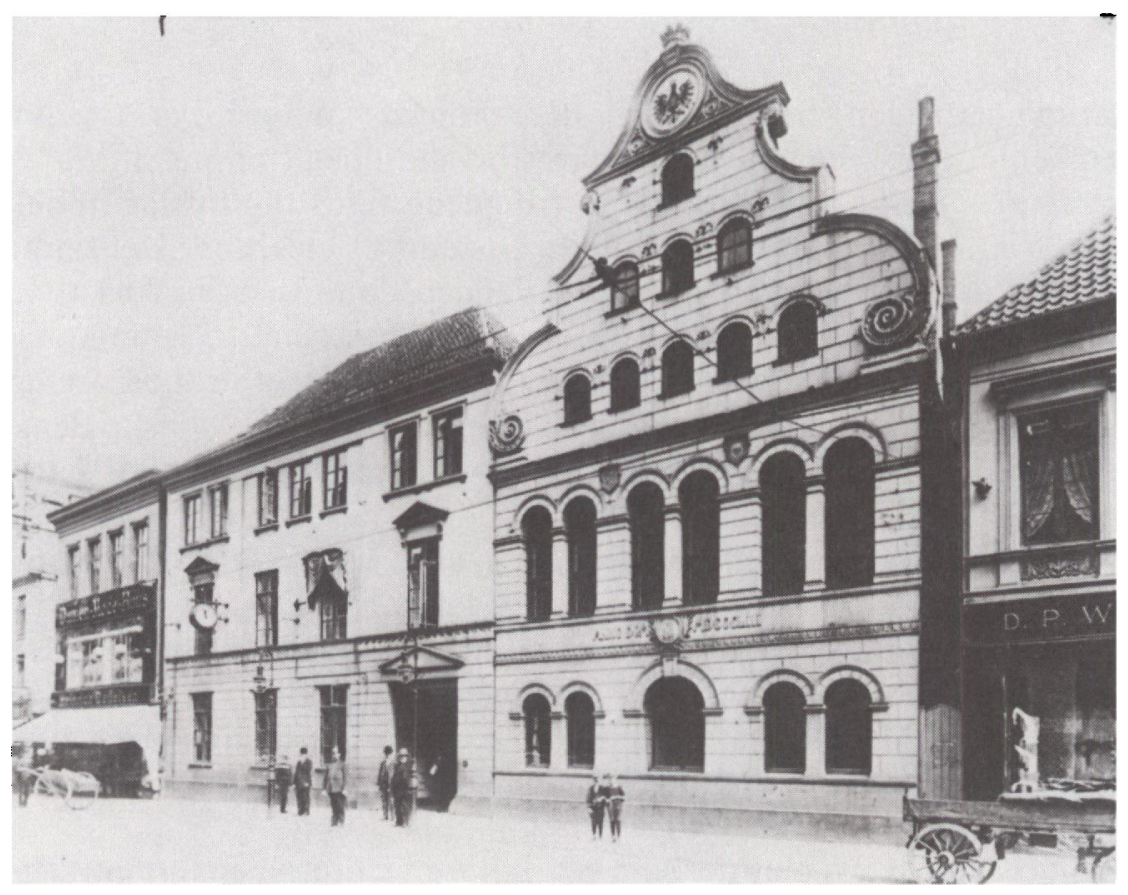

Regeringsbygningens todelte facade mod Holmen. I det klassicistiske hus til venstre blev der indrettet en gastebolig til kongen. Bag de tre dobbeltbuer på forste sal $i$ det barokke gavlhus lå retssalen med L. Frolichs store malerier. Billedet er taget, efter at det danske rigsvåben var blevet udskiftet med den preussiske orn. (Flensborg Byarkiv) 

De to huses facader mod Holmen blev kraftigt renoverede; men karakteren af 2 huse med forskelligt stilpræg, et klassicistisk langhus og et barokt gavlhus, blev bevaret. De største ændringer af det eksisterende kompleks skete ved ombygningen af pakhuset til stænderbygning. Denne bygning blev Winstrups kendteste arbejde.

Stænderbygningen var et typisk senklassicistisk bygningsværk, med et præg af italiensk renæssance. Slægtskabet var tydeligt med Casino fra 1846 i København, den bygning, der dannede rammen om de berømte nationalliberale møder i 1848. Også Casino er blevet revet ned og er erstattet af et »funktionalistisk « hus efter anden verdenskrig. Også det nuværende kongelige teater i København, der er opført noget senere, bærer de samme hovedtræk som stænderhuset: et stærkt gennembrudt, arkadeagtigt midterparti på første sal, der bliver afbalanceret af faste vægpartier i siderne.

Stænderhusets store buevinduer markerede klart bygningens vigtigste rum, stændersalen. Vinduerne blev yderligere fremhævet i facaden gennem buernes kraftige profilering. I denne detalje ser vi tydeligt

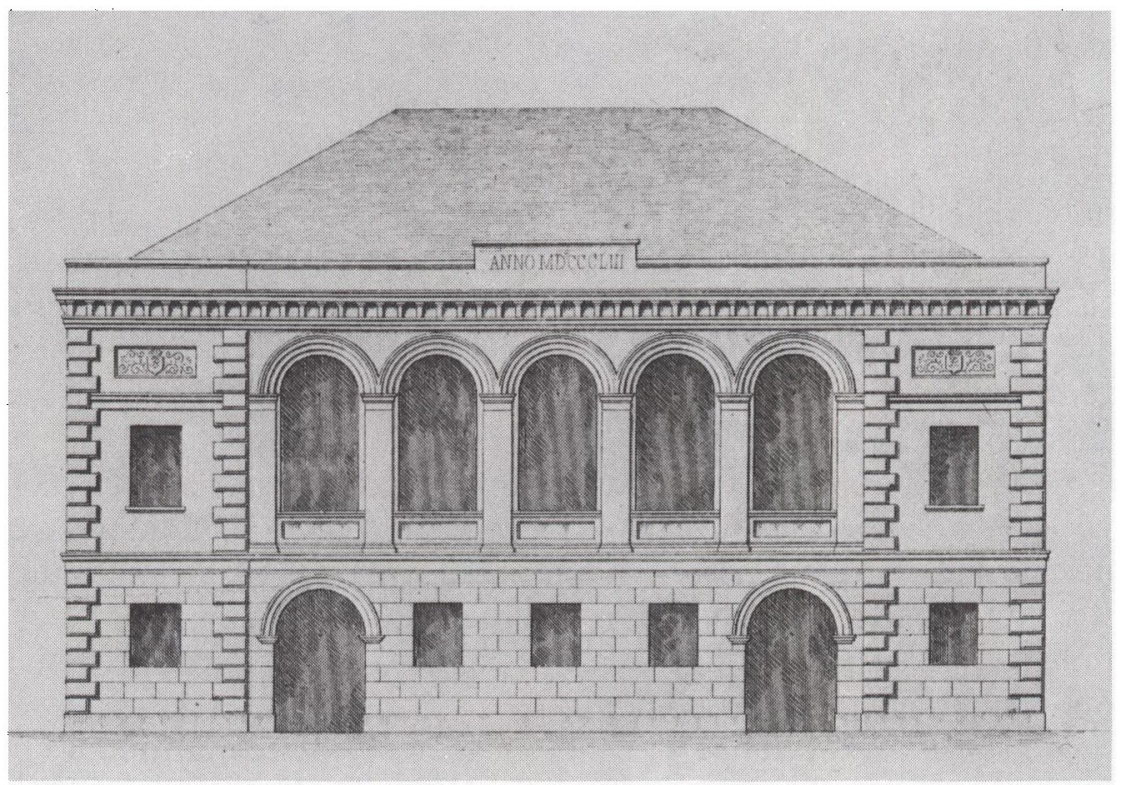

Standerbygningens hovedfacade mod ost. Denne bygning lå overfor banegården ( $n u$ ZOB) og var et ombygget pakhus. Bag forstesalens 5 høje buer lå den fornemt udsmykkede standersal. Gennem de to nederste buer forte passager til de ovrige regeringsbygningers gård. (Kunstakademiets bibliotek) 

større materielle muligheder resulteret i mange væsentlig dårligere tilpasninger af offentligt byggeri til bybilledet.

Også Latin- og realskolen var en byggeopgave med udgangspunkt i en eksisterende bygning. ${ }^{8}$ Den gamle latinskole fra $1806 \mathrm{blev}$ ombygget til bibliotek og festsal. En ny vinkelbygning omsluttede sammen med festsalsfløjen en skolegård og husede klasseværelserne. Hovedindgangen, formet som en triumfbue, vendte ud mod Rødegade. Gården var delvis omgivet af buegange, som var et yndet motiv hos Winstrup. Biblioteket havde sin indgang fra en portbygning kronet af et tårn, under hvilket klostergangen førte i en hvælvet passage. Latinskolens bygninger dannede sammen med biblioteket og klosterbygningen et fint lille "latiner « kvarter lige inden for byens port. De smukt indrammede pladsrum stod i direkte forbindelse med Søndertorv gennem Klostergang og Rødegade. Hele dette intime miljø er nu slået i stykker for at forbedre forholdene for motortrafikken.

Latinskolens hovedfacade mod Rødegade havde Winstrup udformet efter samme hovedprincip som Stænderbygningen. Et midterparti med en sammenhængende række af buede vinduer på 1 . sal blev holdt på plads af to sidepartier. Her var de enkelte led dog udformet med mindre binding til klassicismen. Symmetrien var forladt, og middelalderlige arkitekturdetailler havde fundet indpas. Det nordre sidefags blændingsfacade blev afsluttet med en gotisk kamtakket gavl. Kamtakkerne blev opfattet som særligt nordiske og optrådte i disse år mere og mere i byggerier, som man ønskede at give et nationalt præg. Det syd-

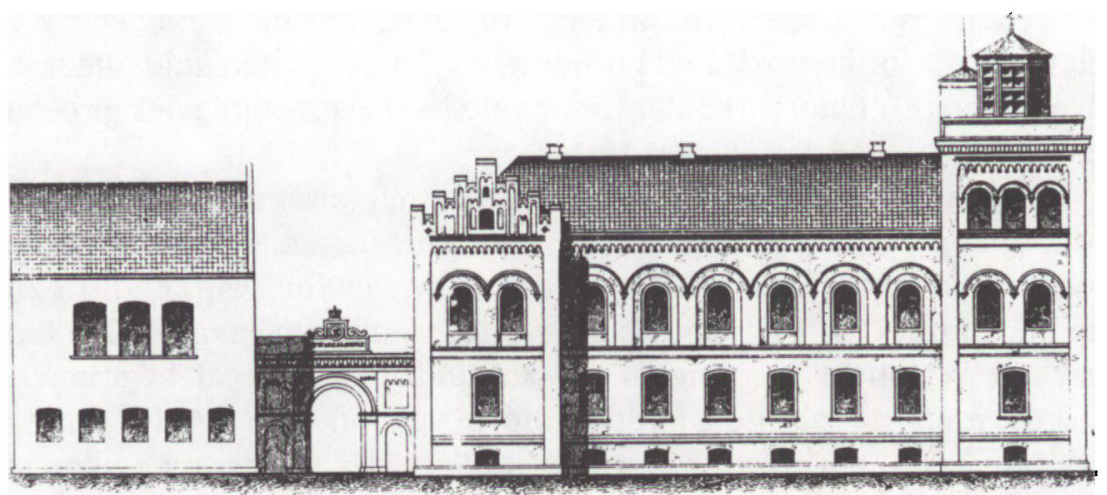

Latinskolens facade mod Rødegade. De to bygningsblokke er forbundet gennem indgangsbygningen, udformet som en triumfbue.

Herfra kom man videre til en arkade $i$ skolepladsens ene side. Klassevarelserne ld pd den store bygnings 1. sal. Helt til hojre et tårn med skolens observatorium. (Trap, 1864) 


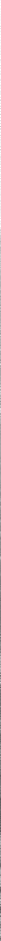

Den af Winstrup ombyggede gamle skole nord for skolegården. Tårnet med buegangene dannede en effektfuld afslutning af Klostergangen. Biblioteket $i$ bygningen til hojre var tankt som en parallel til Universitets-biblioteket $i$ København, men havde nappe muligheder for at nå på dettes niveau. (Flensborg Museum)

lige sidefag nærmest Rødeport var forhøjet med et tårn, der indeholdt skolens observatorium.

Medens Winstrups store arbejder for det offentlige i Flensborg er blevet ofret for kommercielle udnyttelser, kan vi til gengæld glæde os over, at nogle af hans arbejder for private bygherrer stadigvæk er bevarede.

På byens hovedstrøg finder vi to bygninger, Holmen 10 og Storegade 48 , der dog begge er stærkt ombyggede i stueetagen. Holmen 10 er nu "Stadtsparkasse«, men blev oprindeligt bygget for den kendte købmand Andreas Christiansen (3. generation med dette navn). Vi har kun bevaret Winstrups tegning til en ikke udført udgave af bygningens facade, men må formode, at den udførte version også skyldes samme arkitekt.' Her har Winstrup valgt »hollandsk« renæssance som sit hovedmotiv; ganske naturligt for den tids opfattelse, at husets bestemmelse skulle udtrykke sig igennem facadens stilart. Bygningernes plan og facade behandlede periodens arkitekter hver for sig. Til samme plan blev der ofte tegnet flere facader i hver sin stilart. Hollandsk renæs- 


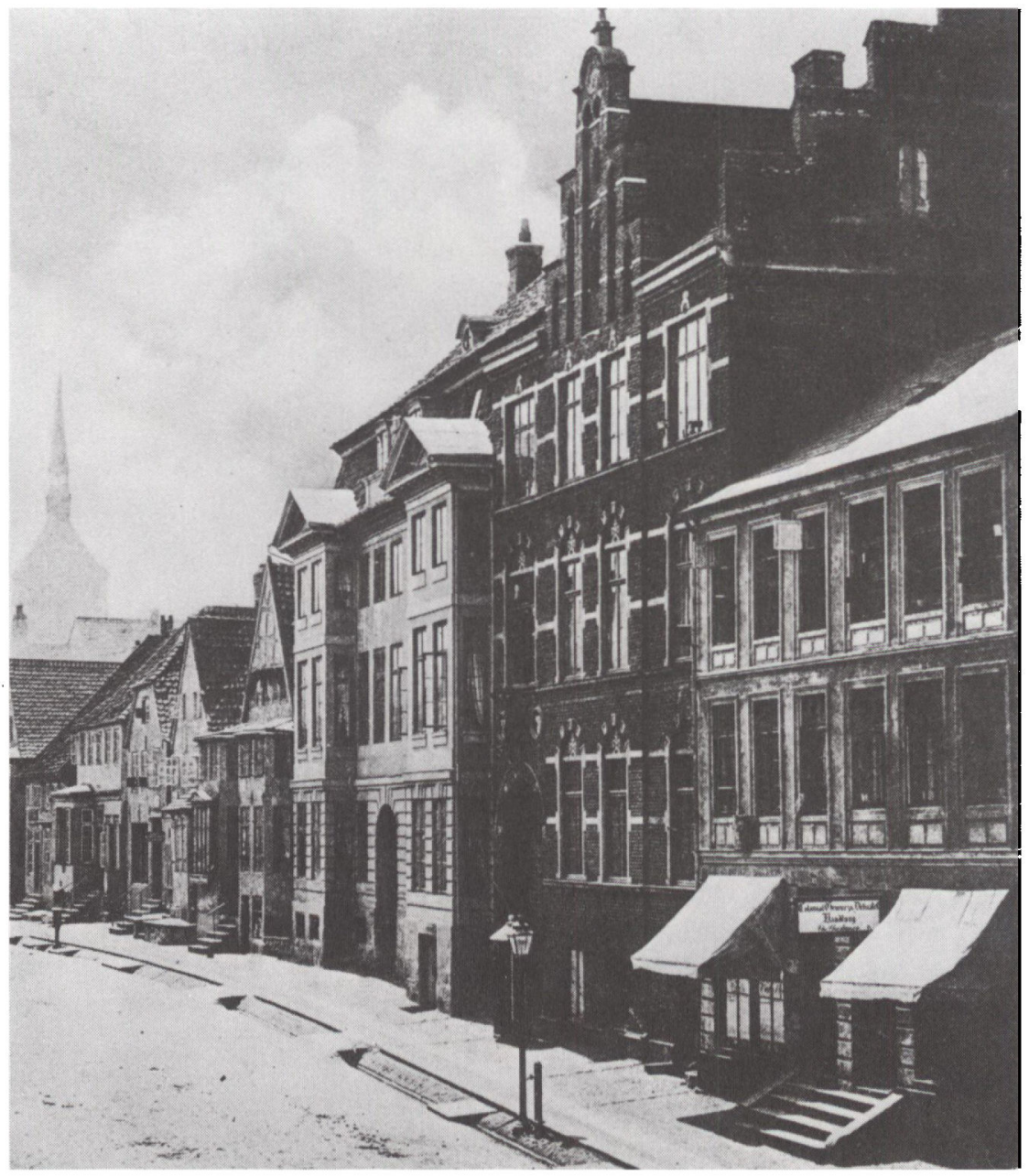

Andreas Christiansens hus pd Holmen (i dag: Stadt-Sparkasse). De nederste etager er nu totalt andrede, men ellers er huset velbevaret.

I baggrunden det gamle Nicolaj-tdrns silhouet. (Flensborg Byarkiv)

sance gav associationer til driftig handelsvirksomhed, og fra denne stil overtog Winstrup de synlige røde mursten og hvide facadebånd. Trappegavlen over midterpartiet viser derimod i sine blændingsmotiver en påvirkning fra sengotiske gavle i Flensborg, som vi f.eks. kender dem fra Nørreport.

Storegade 48 er en ombygning af en ældre købmandsgård, hvor den 

lange facade er blevet forsynet med to trappegavle af lignende type som på Holmen 10, her dog anbragt på de svagt fremspringende sidepartier. ${ }^{10}$ Bygningen har i dag mistet meget af sin oprindelige karakter gennem stueetagens ombygning og de nye vinduer uden sprodser. Desuden er det oprindelige mønstermurværk i røde og gule teglsten blevet overmalet.

Winstrup tegnede et større antal private villaer fortrinsvis til byens højere embedsmænd og velhavende forretningsmænd. Heraf har vi bevaret det nuværende Lutherhaus (Søndergravene, bagved Nicolaj kirke) og Reberbane 34 (ved den gamle kirkegård).

Lutherhaus blev bygget for bysekretæren, justitsråd Hargens og står i det ydre som Winstrups mest velbevarede bygning. I sin arkitektur repræsenterer huset en bygningstype, der fik sit gennembrud i disse år og kom til at præge middelstandens villakvarterer i mange årtier. Hvor klassicismens landsteder havde været strengt symmetriske anlæg både i plan og facader, som f.eks. C.F. Hansens værker i Altona, blev bygningskroppen nu en romantisk komposition af forskellige formelementer.

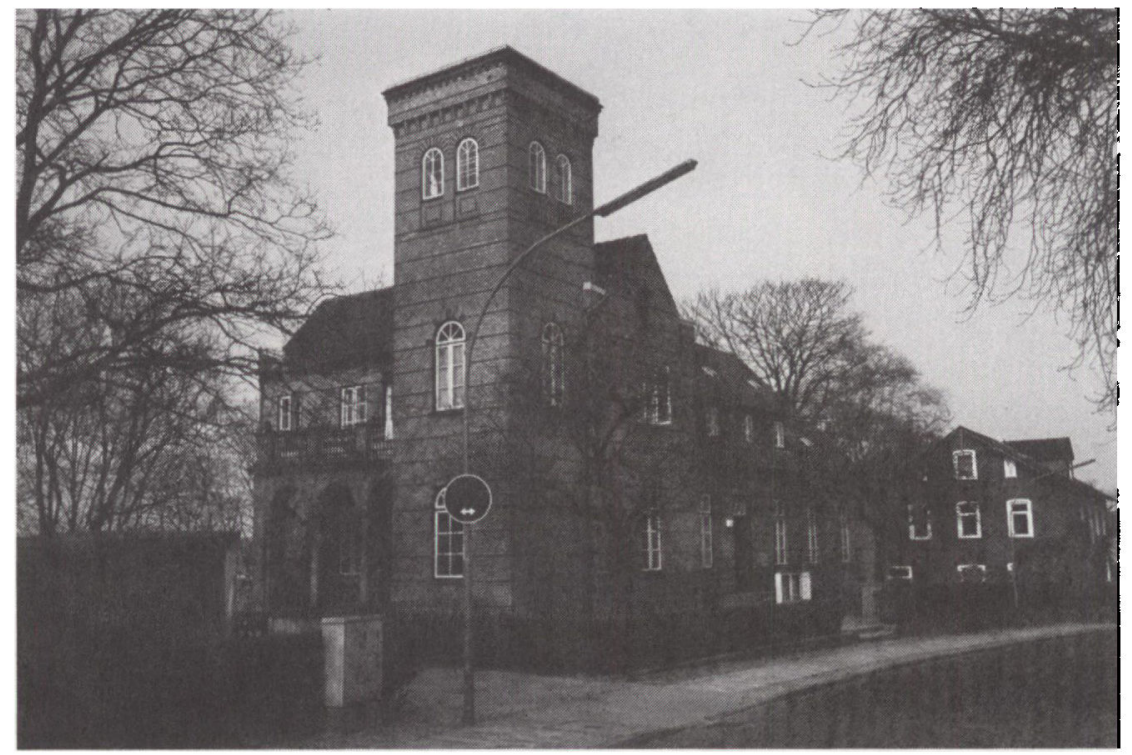

Hargens hus (Lutherhaus), den bedst bevarede af Winstrups bygninger. Her ses tårnet, der knytter sig til den to-etagers bygning som en italiensk campanile til sit kirkeskib. I fortsattelse af to̊rnet ligger arkaden med en balkon på toppen. (Foto: Hans Munk Hansen) 


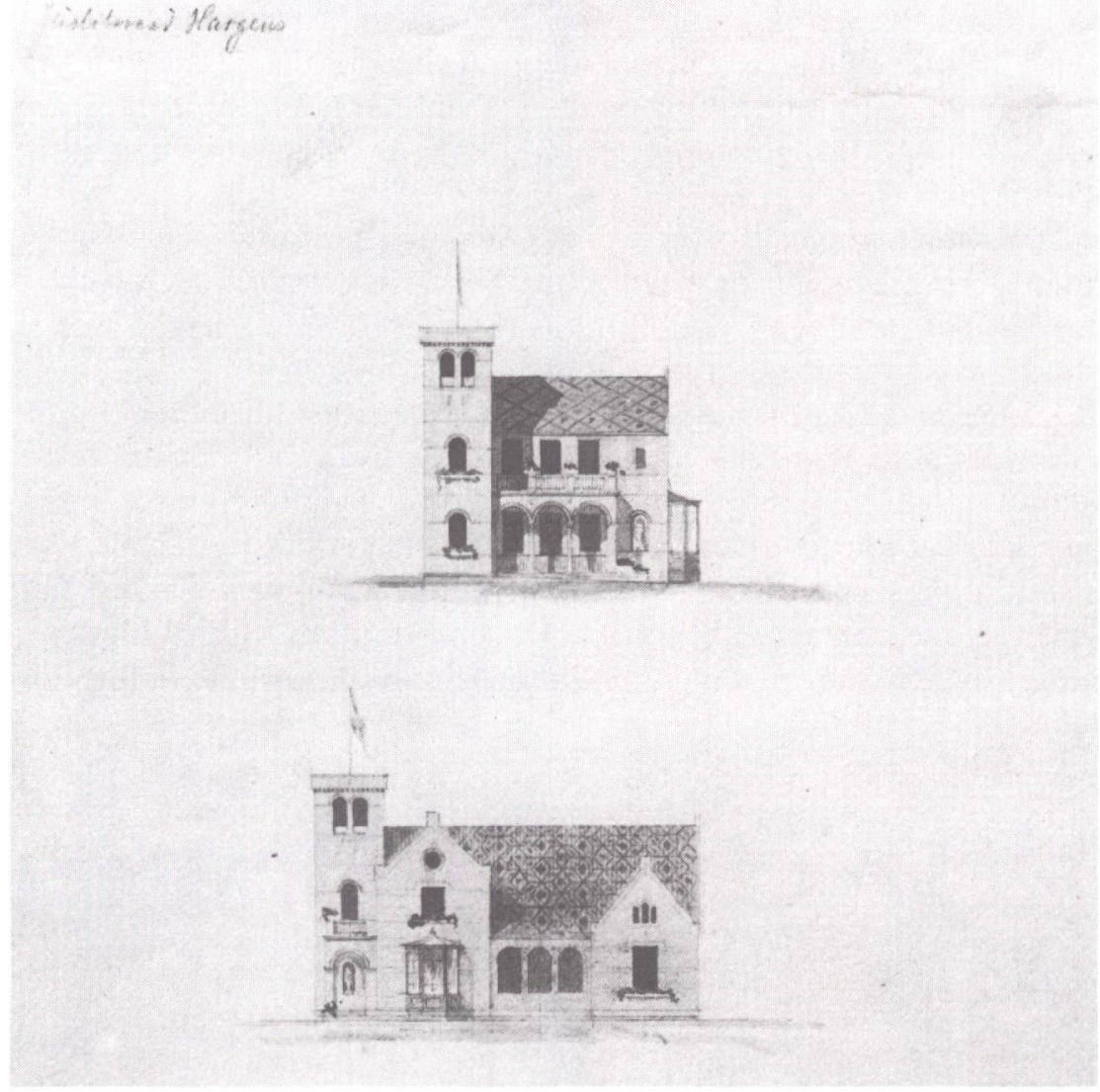

Winstrups tegning til Hargens hus, nu: Lutherhaus (Rigsarkivet).

Inspirationskilden var anonyme italienske landhuse. Schinkel havde allerede i 1830-erne bygget huse af denne type i Berlin og Potsdam (Charlottenhof, Gärtnerhaus), ${ }^{12}$ og i København holdt den romantiske villa sit indtog med Herholdts Tårnborg i $1846 .{ }^{13}$ Lutherhaus er en énetages bred bygning med saddeltag, der i syd støder op mod en smal, tværstillet bygningsblok $i$ to etager. Huset domineres af et treetagers tårn i sydvesthjørnet. Herfra strækker der sig en rigt udsmykket arkade med en balkon på toppen foran sydfacaden, medens østfacaden ned mod byen er smykket med en karnap. Arkader og karnapper var Winstrups yndlingsmotiver, som han anvendte, hvor det var muligt. Faca- 
den er af gule teglsten, opdelt af røde bånd. Tårnets øverste etage er særligt rigt dekoreret med middelalderlige murstensornamenter.

Arkadens og balkonens rækværk er udført i støbejern, som på den tid var et nyt materiale i husbygningen. Støbejernets muligheder blev erkendtaf Schinkel, som havde brugt dette materiale til bl.a. gravmonumenter (i Flensborg to gravmæler på den gamle kirkegård). Til trods for den italiensk inspirerede komposition forekommer huset dog ret hjemligt. Hertil medvirker stofkarakteren af de lokale mursten og de spidse gavle uden tagudhæng.

Langt mere sydlandsk virker Winstrups anden bevarede villa, Reberbane 34 jernbanedirektør Lauths villa. ${ }^{14} \mathrm{Her}$ afsluttes huset med lave skifertage med udhæng. Murene er glatpudsede og hvidmalede. Bygningskroppen er formet som et uregelmæssigt $\mathrm{H}$, hvor fremspringene i begge facader er formet forskelligt. I nordhjørnet rejser sig et tårn, hvis øverste etage er typisk senklassicistisk med sine regelmæssige opdelinger i piller og åbninger. Husets facader bugner af mangeartede klassicistiske dekorationer. Hertil kommer en rigt udstyret karnap mod øst. I det indre går husets store hall igennem to etager og får lyset fra oven; tidligere gennem en lanterne, som nu er erstattet af et glastag.

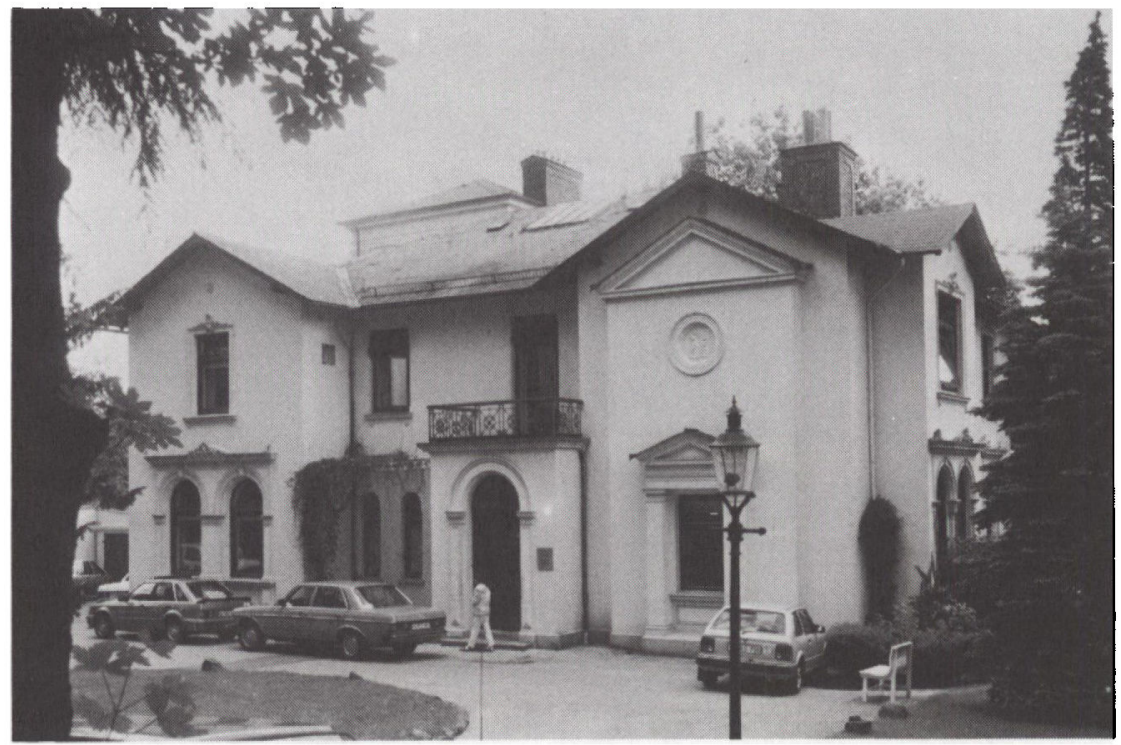

Indgangssiden til jernbanedirektor Lauths hus pd Reberbanen. Det hvide hus er dakket med skifertage. Pd husets modsatte side står tdrnet med udsigt over byen. (Foto: Hans Munk Hansen) 


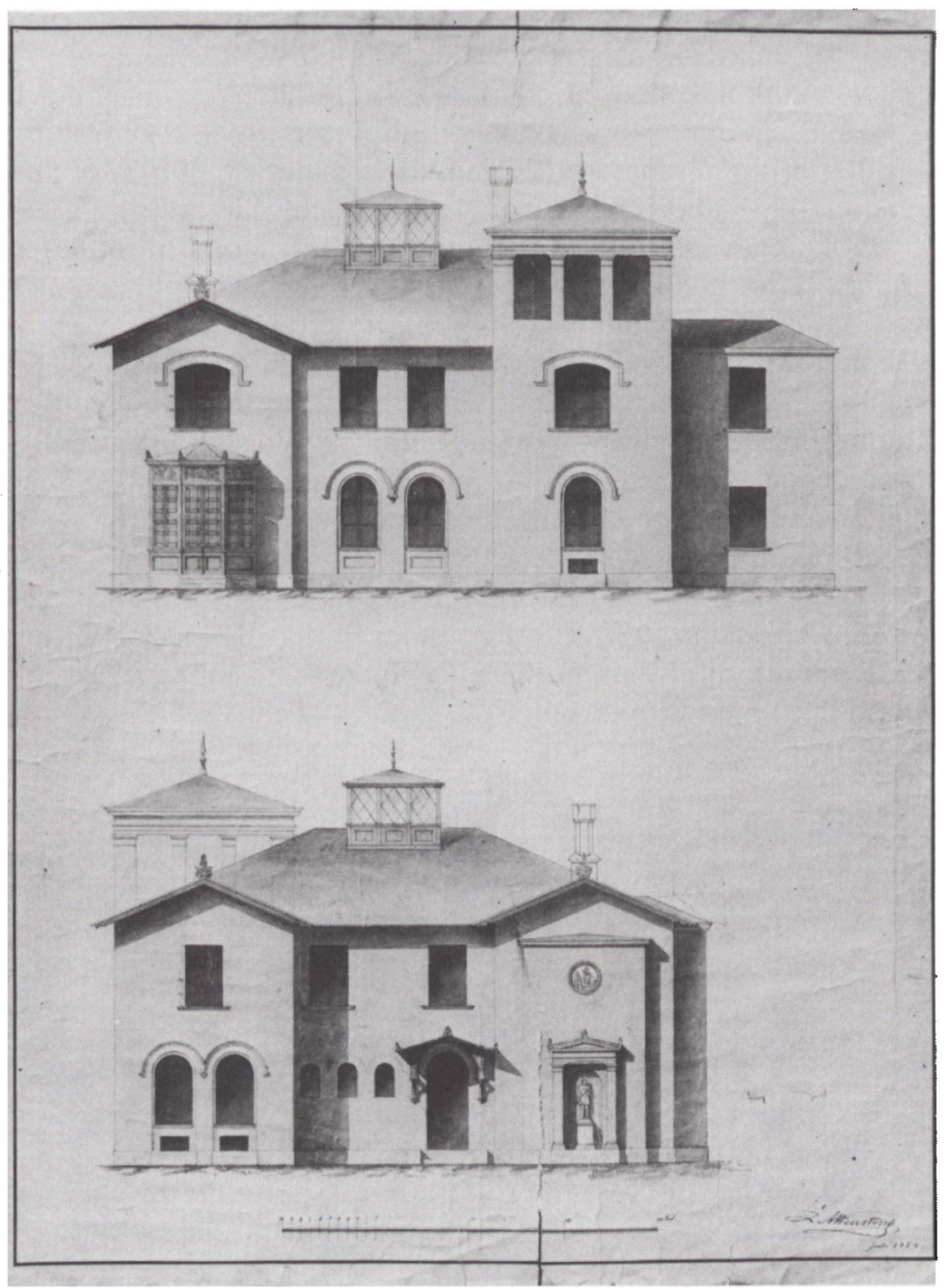

Winstrups tegning til jernbanedirektorens hus (Rigsarkivet). 
Winstrups tegninger til huset bærer engelske påskrifter, hvilket bekræfter, at bygherren var englænder, tilknyttet jernbanen Flensborg - Tønning. Winstrup har i dette hus naturligt nok søgt at tilnærme sig tidens engelske arkitektur, som han havde stiftet bekendtdkab med på en rejse til London.

Ud over sine byggeopgaver udførte Winstrup en række dekorative arbejder, bl.a. en gravsten for Christian Paulsen på den gl. kirkegård. ${ }^{15}$ Det er en klassicistisk stele med et indføjet relief, der fremstiller en genius med sænket fakkel.

I sin levetid var Winstrup en anerkendt kunstner. Senere blev hans arbejder dog vurderet mindre positivt, en skæbne, han måtte dele med de fleste af periodens øvrige arkitekter. I Eklekticismens tid var man forarget over den frie sammenstilling af forskellige tidsperioders arkitektur, og under funktionalismen kunne man ikke acceptere, at bygninger med samme plan kunne iklædes forskellige facader. Funktionalismen har imidlertid i de senere år mødt stærkere og stærkere folkelig modstand, og arkitekter søger igen som i 1850'erne efter løsninger, der kan berige os med større oplevelser.

I modsætning til Winstrup er Gottlieb Bindesbøll (1800-56) altid blevet berømmet af sin eftertid. En enkelt arkitekturhistoriker går så vidt som at kalde ham "århundredets originaleste danske arkitekbegavelse«. ${ }^{16}$

Bindesbøll havde samme uddannelsesmæssige baggrund som Winstrup. Også han vandt kunstakademiets store guldmedalje, på en gotisk katedral, indtil da et uhørt projekt i klassicismen højborg. ${ }^{17}$ Som ung studerende havde Bindesbøll været i Tyskland som H.C. Ørsteds rejseledsager og i Weimar fået foretræde for Goethe. ${ }^{18}$ Den store digter havde talt med ham om gotikken, især Kølns domkirke. Efter afslutningen af studierne og hjemkomsten fra et længere ophold i Rom blev Bindesbøll bygningsinspektør for Holsten og boede en periode $i$ Altona. Hans væsentlige opgave var her restaureringen af kirken i Bordesholm.

Bindesbølls opgaver i Flensborg var formidlet gennem justitsråd C.M. Poulsen, generaldirektør i det engelske jernbaneselskab. Poulsens egen bolig ved Bov Landevej, Villa Sollie, blev en milepæl i udviklingen af det danske énfamiliehus. ${ }^{19}$

I romantikkens søgen efter den "nordiske bolig " havde man indtil da forsøgt sig med "schweizerhuse», norske bjælkehytter og lignende. Således havde Bindesbøll tegnet et hus til Orla Lehmann i en ret kunstig »saga-stil«. Med Villa Sollie tog Bindesbøll det nye, idag ganske 

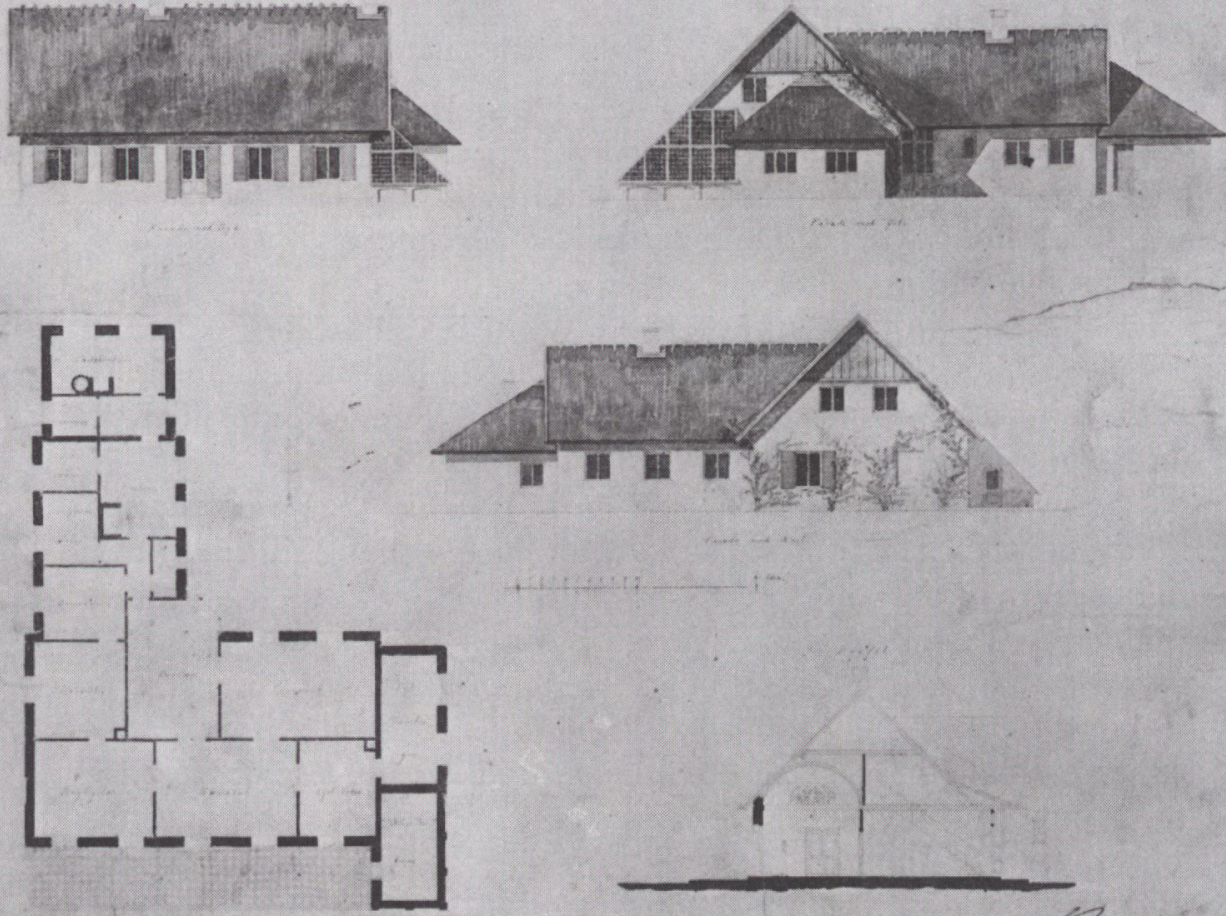

Villa Solie ved Bov Landevej er den eneste endnu delvis bevarede af Bindesbolls bygninger $i$ Flensborg. Villaen har spillet en vasentlig rolle i det danske énfamiliehus' udvikling.

selvfølgelige skridt, at hente inspiration fra det jævne landhus. For tidens digtere og malere var det lille hus på landet allerede et yndet motiv. Bindesbøll var derimod den første arkitekt, der så mulighederne for en fornyelse af arkitekturen gennem den folkelige byggetradition. Villa Sollie var i det ydre et hvidkalket stråtækt hus, der var bygget i vinkelform. ${ }^{20} \mathrm{På} \mathrm{samme} \mathrm{måde} \mathrm{som} \mathrm{i} \mathrm{et} \mathrm{husmandshus} \mathrm{rummede} \mathrm{hoved-}$ fløjen stuerne, medens den smallere sidefløj indeholdt sekundære rum. Den femfags hovedfacade er symmetrisk bygget op omkring havedøren. Et lavt væksthus ved den ene gavl sørgede dog for, at denne symmetri ikke blev alt for konsekvent. Også på anden vis tog Bindesbøll sig nogle friheder ved fortolkningen af den regionale stil. Gavlene, som på Flensborgegnen i denne periode næsten altid var afsluttet med halvvalme, blev på Villa Sollie til spidsgavle med træbeklædning. Her har Bindesbøll sikkert tænkt på sin barndoms sjællandske landsbyhuse.

Villaen var for øvrigt på ingen måde et beskedent hus, som dets ydre 
kunne antyde. Især den hvælvede havesal var et fornemt udstyret rum. Maleren Lorenz Frølich havde her dekoreret de buede endevægge med malede motiver fra den nordiske mytologi. ${ }^{21}$ Disse malerier eksisterer endnu og er ophængt på Snoghøj Højskole.

Villa Sollie og Winstrups villa ved Reberbanen er bygget omtrent samtidig, ovenikøbet til bygherrer, der var direktører i samme foretagende. I dag er det svært at forstå, at arkitekter med samme baggrund kunne nå frem til to så vidt forskellige løsninger af den samme opgave. For eftertiden fik Bindesbølls hus den største betydning af de to. Vor tids danske typehus står således i stor gæld til Villa Sollie.

Bindesbøll tegnede også alle stationer på den slesvigske jernbane fra Flensborg til Tønning. De mindre stationsbygninger var præget af den saglige strømning, som Bindesbøll var optaget af i sine sidste leveår. På hovedbanegården i Flensborg har Bindesbøll dog anset det for nødvendigt med en pretentiøs facadeudformning. Foran den overdækkede toghal var der her sat en facadebygning i en frit bearbejdet nederlandsk renæssance $i$ mursten med hvide bånd.

Denne bygning var i det oprindelige projekt formet som et omvendt $\mathrm{U}$, hvor spidserne var forsynet med portaler til henholdsvis postkontor

Bindesbølls projekt til banegdrden i Flensborg. Senere blev planen vasentligt udviket. (Kunstakademiets bibliotek)

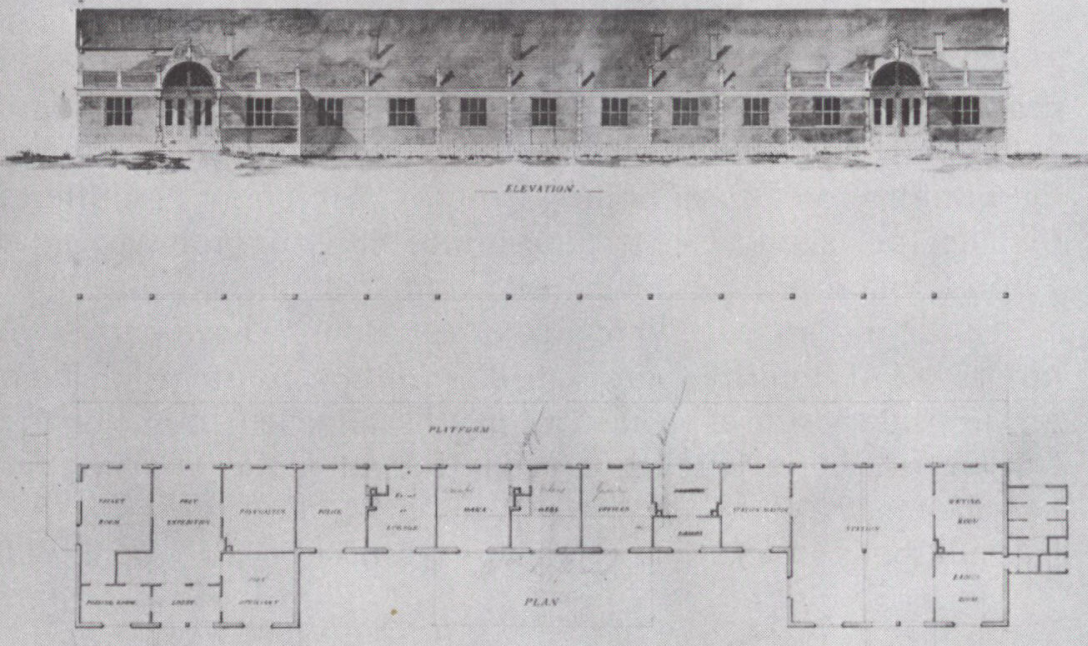




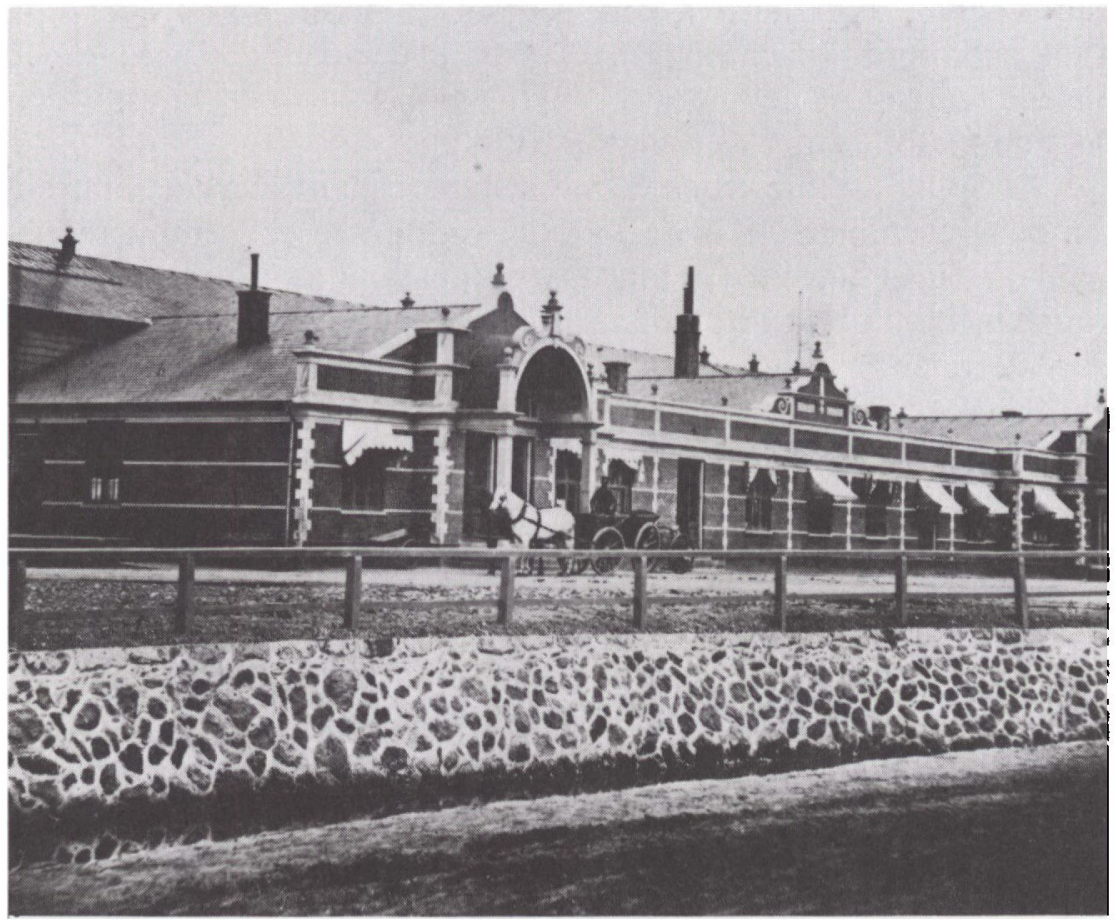

Jernbanelinien Flensborg-Tonnings hovedbanegård lå $i$ Flensborg, hvor nu "ZOB" er placeret. Den venstre portal (bag hestevognen) forte ind til posthuset og afsluttede blikket gennem den nyanlagte Rådhusgade. (Flensborg Byarkiv)

og ventesal. Den forbindende smalle fløj indeholdt forskellige kontorer. Ved opførelsen af stationen blev dog mellemrummet mellem endefløjene udfyldt, og midten blev markeret med en tredie renæssancegavl. Dette svækkede i nogen grad den oprindelige komposition.

I planen for ventesalsfløjen bemærker man, at der udover det egentlige »waiting room « også er indrettet et »ladies room《. Påskrifterne på tegningerne var engelske af hensyn til jernbanens grundlægger, S.M. Peto i London.

Selve toghallen må efter tegningerne at dømme have været et overordentlig fint rum overdækket med en elegant konstruktion. Hallens ene langside bestod af en åben arkade af samme lethed som en florentisk loggia. Det er sørgeligt, at vi ikke har fotografier af denne side af banegården.

Bindesbølls projekt til et nyt rådhus i Flensborg på det gamle rådhus 


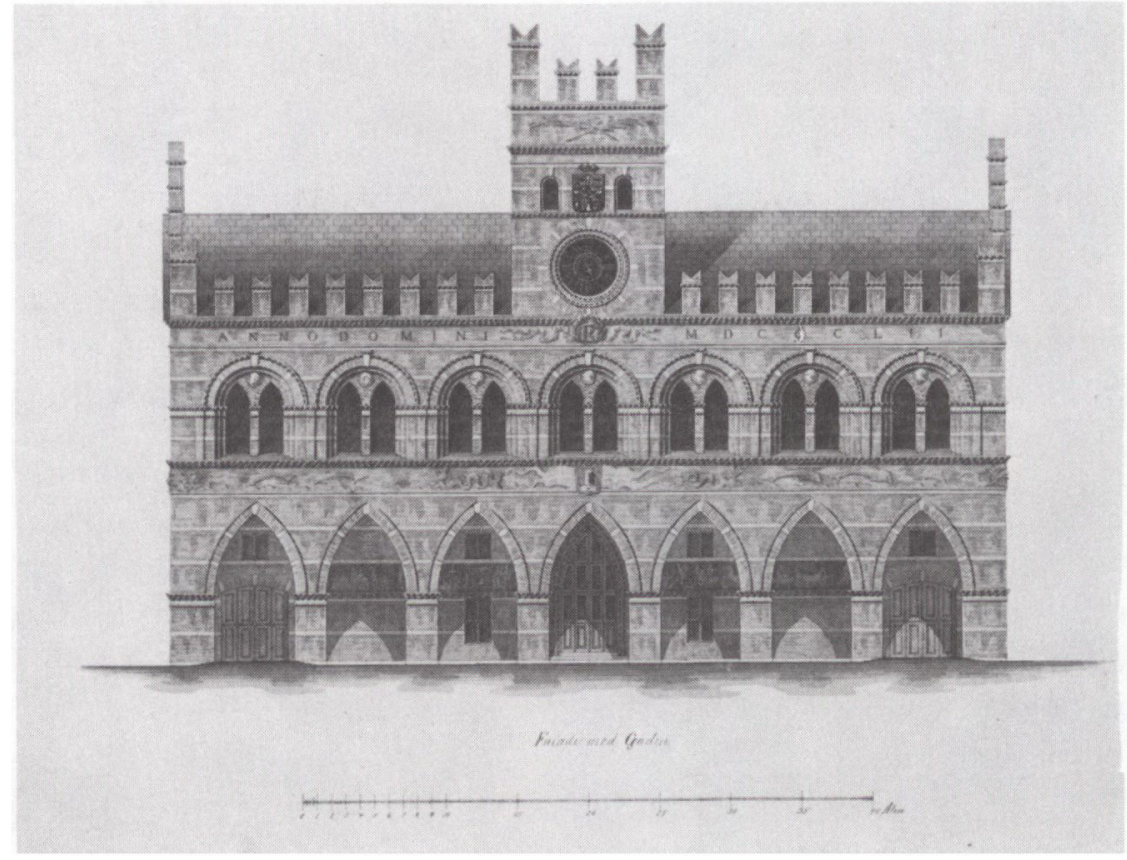

Bindesbolls ikke opforte projekt til et nyt radhus i Flensborg, pd det middelalderlige rddhus' sted. (Kunstakademiets bibliotek)

plads (nu Mac Donald) blev ikke opført. Rådhuset var tænkt i to etager med et lille tårn i midten. I stueetagen var der indfældet en åben buegang, fra hvilken der var adgang til en hall, der gik igennem begge etager. Herfra skulle man komme til en stor højloftet sal i en fløj bagud.

Efter Bindesbølls død i 1856 trådte J. D. Herholdt (1818-1902) frem som landets mest betydningsfulde arkitekt. Herholdt, der nedstammede fra den kendte lægefamilie i Åbenrå, løste store offentlige byggeopgaver i København såsom Hovedbanegården, Universitetsbiblioteket og Nationalbanken. Også Herholdt arbejdede i mange forskellige stilarter, som han bearbejdede frit.

I Flensborg byggede Herholdt kun en enkelt bygning, der tilmed er forsvundet igen: Justitsråd Raasløfs villa ved Duborggade. ${ }^{22}$ H.J.A. Raasløf flyttede allerede i 1854 til København, da han blev departementschef og senere minister for Slesvig.

Raasløfs hus var bygget i nederlandsk renæssance af gule teglsten opdelt med røde bånd. Huset var afsluttet med »vælske« gavle i begge 


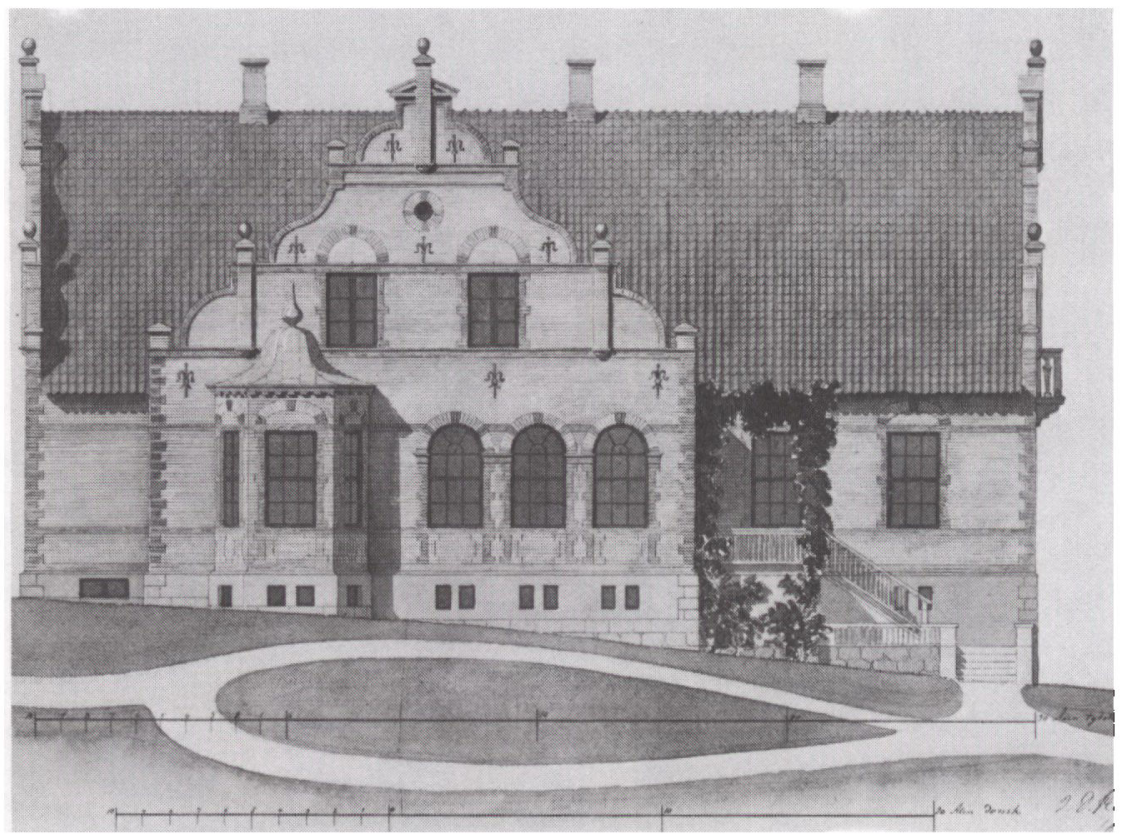

J. D. Herholdts tegning til villaen for justitsråd Råsløf, 1851. Her er vist havefacaden med den store havetrappe til højre for den fremspringende gavl. (Kunstakademiets bibliotek)

sider. Hertil kom et fremspringende parti i hovedfacaden med en lignende gavl, her dog fremhævet med en usymmetrisk anbragt karnap. Det skrånende terræn blev udnyttet til anlæg af en stor trappe foran havedøren.

Den sidste af periodens kendte danske arkitekter fra københavnerskolen, der virkede i Flensborg, var Hans J. Holm (1835-1916). I 1873 tegnede han Østersøbadet nord for byen ved Klues Skov. ${ }^{23}$ Badeanlæg ved strandene var en af tidens nye byggeopgaver. Bindesbøll havde således allerede to årtier tidligere projekteret den fashionable Klampenborg badeanstalt nord for København. Klientellet var det velsituerede borgerskab, der søgte sundhed og nok lige så meget selskabelighed i naturen. Østersøbadet blev dog aldrig den store succes. Det var anlagt af et aktieselskab, der dog snart måtte give op og sælge til kommunen. Det ekspanderende værft kom tættere og tættere op mod badeanlægget og bidrog ikke til følelsen af uberørt natur. Det er dog kun få år siden, den sidste af Østersøbadets bygninger blev revet ned efter i mange år at have tjent helt andre formål. 
Hans J. Holms projekt til Østersøbadet havde som central bygning en café-restaurant med vid udsigt over fjorden. I grundens periferi lå såkaldte "cottager« med badegæsternes sove- og opholdsrum. Et stort hotel var planlagt, men blev aldrig udført. Direkte ved stranden lå en badeanstalt til "varme- og styrtebade«.

Hans J. Holm holdt sine bygninger i en streng italiensk renæssance. Forbi var perioden med den frie fabuleren over tidligere epokers bygningsformer. $\mathrm{Nu}$ herskede den akademisk korrekte stileklekticisme.

\section{NOTER OG HENVISNINGER}

1. Knud Millech: Danske arkitekturstrømninger 1850-1950.

2. E. Bondo Svane: L.A. Winstrups vigtigste arbejder; i Sjy. Årb. 1946.

3. Winstrups tegninger i Kunstakademiets bibliotek, tegningssamlingen.

4. Winstrup arkivet, Rigsarkivet.

5. Winstrup arkivets tegningssamling, Rigsarkivet.

H. J. Holms helhedsplan for Østersøbadet (beliggende umiddelbart nord for det nuvarende skibsvarft). Omkring den centrale restaurant ligger "Cottager", et hotel og nede ved stranden en badeanstalt. (Kunstakademiets bibliotek)

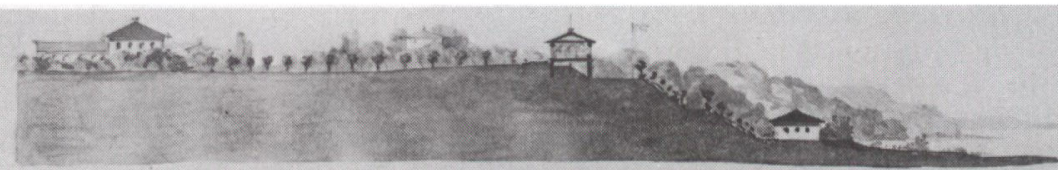




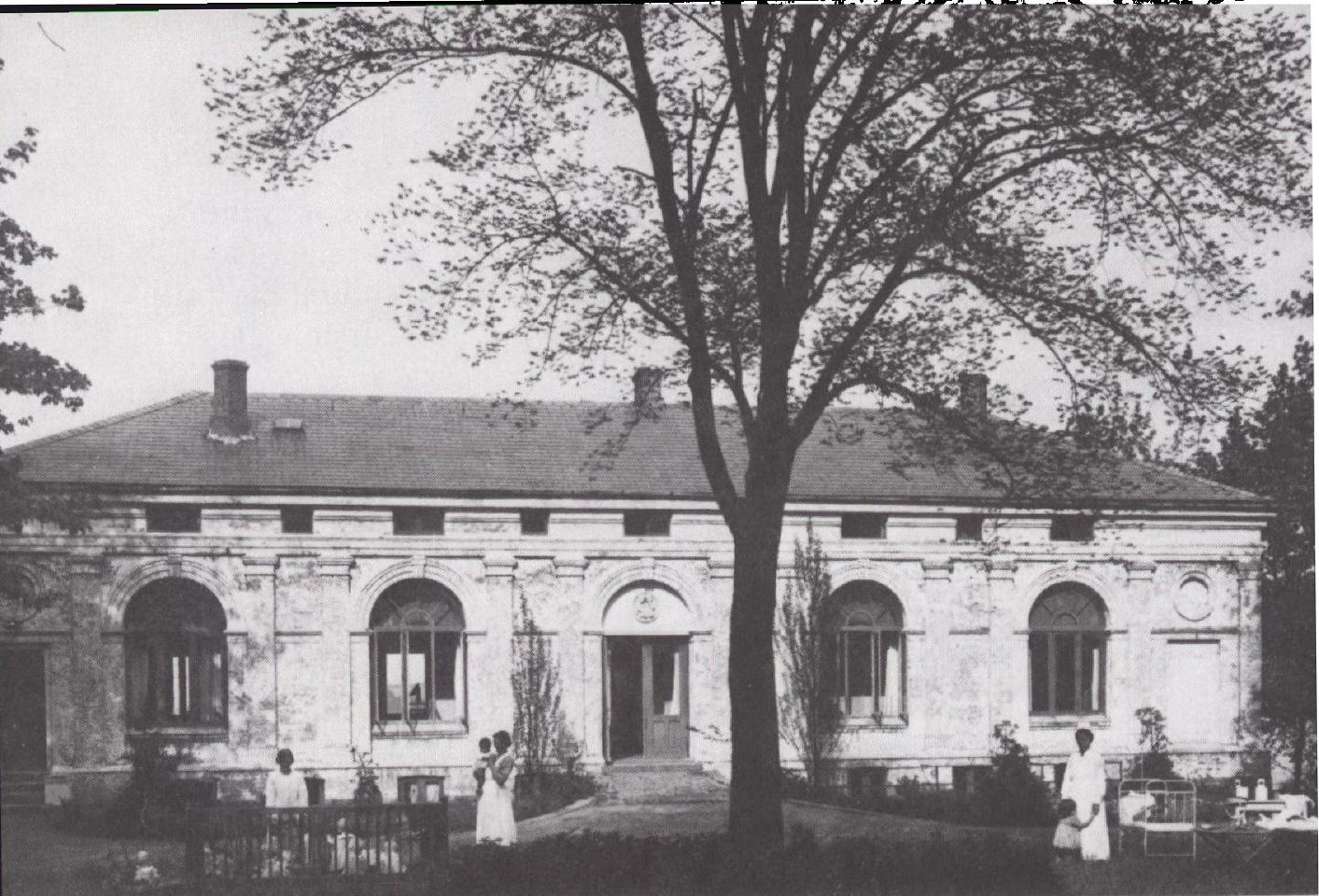

Ostersøbadets restaurant set fra indgangsiden, da bygningen var omdannet til bornehjem. Den anden side vendte med to etager ud til en storslaet udsigt over Flensborg Fjord. (Flensborg Byarkiv)

6. H. Glarbo: Lorentz Frølich og hans billeder i appelationsrettens sal i Flensborg; i Tilskueren 1930.

7. Winstruparkivets tegningssamling, Rigsarkivet.

8. Winstruparkivets tegningssamling, Rigsarkivet.

9. Winstruparkivets tegningssamling, Rigsarkivet.

10. Winstruparkivets tegningssamling, Rigsarkivet.

11. Winstruparkivets tegningssamling, Rigsarkivet.

12. Postdam, Sanssouci, Aquarell-Sammlung nr. 2110.

13. L. Balslev-Jørgensen, Eenfamiliehuset, 1979.

14. Winstrup arkivets tegningssamling, Rigsarkivet.

15. Winstrup arkivets tegningssamling, Rigsarkivet.

16. T. Faber i Dansk Arkitektur, 1963.

17. Kunstakademiets bibliotek, tegningssamlingen.

18. H. Bramsen: Gottlieb Bindesbøll, 1959.

19. F. Hendriksen i Architekten, 1918 nr. 39.

20. Kunstakademiets bibliotek, tegningssamlingen.

21. Børge L. Barløse: Lorenz Frølich i Flensborg, i Sjy. Ȧrb. 1984.

22. Johan Daniel Herholdt og hans værker, udgivet af hans elever. København 1898.

23. Kunstakademiets bibliotek, tegningssamlingen. 